\title{
Nationalism in Multi-Religious Nations: The Albanian and the United States Case
}

\author{
Nereida Shqerra \\ $\mathrm{PhD}$ Cand. \\ QSA (Qendra e Studimeve Albanologjike) \\ nereidashqerra@hotmail.com
}

\begin{abstract}
The aim of this study is to demonstrate that a nation can be created even if its members belong to different religious beliefs. The common religion is a component of nationalism. It plays a role in the consolidation of the shared identity of the members of its nation, so, in the consolidation of the nation itself. Many (or more or less all) nation states have no more than one religion which has supported the consolidation of their national identity. In fact there are few cases in which the members of a nation belong to diverse religious beliefs and almost no study has been focused on this subject. This essay is focused in the formation of the Albanian nation whose members belong to diverse religious beliefs. It studies the way in which Albanian nation took shape even though its members belonged to diverse religious beliefs. There were two ways which brought to the complete consolidation of the Albanian nation. The first one was the negligence toward different religious beliefs that Albanian patriots embodied to the members of their nation, and the second is the role its elites and the state played in the consolidation of the Albanian nation. The conclusions drawn from this case study are that the formation of Albanian nation required negligence toward different existing religious beliefs as well as their self-government in order to make them really Albanian. In other words, the consolidation of the Albanian nation was achieved because Albanians placed nationalism beyond religious beliefs and feelings. The Albanian case is supported by scholars' conclusions about the American nation -which is made of members belonging to different religions- who consider nationalism in the United States as "the most powerful religion in the United States" [Marvin C. \& Ingle D. 1996]; a sentence perfectly suited for Albanian nationalism.
\end{abstract}

Keywords: Nation, religion, identity, Albania.

\section{Introduction}

Primordialists consider the common religion as a component of nationalism jointly with common language, origin, enemy, territory and culture. The common religion of the members of a nation, or nation state, contributes to the national unity because of the shared identity it embodies to its members, creating a common bond among the members of the nation in support of their national identity, contributing thus to the national unity.

The emergence of Albanian nationalism became evident in the 19th century - almost one century after the birth of nationalism in Europe- with the decline of the Ottoman Empire. The fell of Ottoman Empire stimulated Albanians and Kosovars to join their forces against Ottomans and Serbs and they founded the League of Prizren in 1878. Their unification induced by their common enemy, language, culture and origin showed that they constituted a nation; a nation which endeavored to create its nation state, but, the common religion, which would bind its people and would enforce the shared identity of Albanians, was missing. It was a nation with diverse religious beliefs which could not assist in the full consolidation of Albanian nationalism. Albania had many religious communities -Orthodox, Muslims, Bektashi, and Christian- which, though in the form of multiple identities, identified Albanians as Orthodox, Muslim, Bektashi, Christian and Albanians simultaneously. What's more, these religious beliefs were subordinated from abroad. The identity they embodied was not absolutely national.

In order to encourage the spirit of nationalism, the patriots of the Albanian Resurrection (1830-1912) induced a kind of disregard toward the different existing religious to Albanians, because diverse religious beliefs would only separate and demarcate Albanians and would not identify them as totally Albanians [Prifti, ,1993, 7-8]. The famous Albanian patriot of that time Pashko Vasa wrote "Do not see mosques and churches, the religion of Albanians is being Albanian". These words not only induced a kind of disregard toward religions (neglected religion) but, in the same time, they locate the spirit of nationalism beyond religious beliefs.

Marvin C. and Ingle D. [1996] convey the same ideas about the United States' nation: "we contend that nationalism is the most powerful religion in the United States, and perhaps in many other countries. Structurally speaking, nationalism mirrors sectarian belief systems such as Christianity, Judaism, Islam and others that are more conventionally labeled as 
religious. It happens that nationalism also satisfies many traditional definitions of religion, but citizens of nation-states have religious reasons for denying it...Some citizens openly speak of the American flag as sacred. Can we disregard the impassioned testimony of others that it is not, and neither is the nation it represents?".

As a valuation of their article Hawking S. [2013] concludes that "the religion of which they speak is American nationalism". Hawking S. [2013] equalizes religions in the United States with nationalism and moves forward Marvin's C. and Ingle's D. [1996] thoughts by creating his list of similarities between religious beliefs and American nationalism:

"' God = United States of America

Sacred Texts $=$ Constitution $/$ Declaration of Independence

Exegetical Texts $=$ Laws/Gettysburg Address

Sacred Ritual Object = Flag" [Hawking S. 2013]

Although Marvin C. and Ingle D. [1996] in their article speak exclusively about the United States, and do not mention other nations like the Albanian one which has embodied the same principles and ideas about nationalism, reach a generalization which unquestionably is relevant for other nations: "Although our examples come mostly from the United States and its majority sectarian faith, and although generalization is risky, the principles we describe are broadly applicable to other enduring groups, defined as groups for which members are willing to give their lives".

Further than the case of the United States' citizens, who may be considered to have equalized (and not replaced) nationalism with religion, Albanians in reality neglect religions or even may be considered as atheists. In a way, it seems that nationalism has partly replaced religion; as "long-dominant modernizationist arguments, emphasizing socioeconomic modernity (Gellner 1983, Deutsch 1953), political modernity (Breuilly 1994, Tilly 1996, Hechter 2000), or cultural modernity (Anderson 1991)" [Brubaker Rogers 2011, 22] saw or considered it. The reasons for their negligence toward religions may be many- as the denial of the religious believes during the communist period for example - and this negligence may require a specific study, but, indisputably, one of the reasons is the spirit of nationalism which was able to overshadow or "mirror sectarian belief systems such as Christianity, (Orthodox), Islam and others that are more conventionally labeled as religious" [Marvin C. and Ingle D. 1996]; a nationalist sense embodied by Albanian patriots of the period 1839-1912 and so willingly actualized by Albanians.

Another effort of Albanian patriots of the period 1839-1912 was to make the Albanian Religions self-governing. Many of them like Petro Nini Luarasi, Naum Veqilharxhi, Papa Kristo Negovani, At Stath Melani, were killed by Greek chauvinists in their efforts to create The Albanian Autocephalous Orthodox Church (Kisha Ortodokse Autogefale Shqiptare). Later on, Fan Noli succeeded to create The Albanian Autocephalous Orthodox Church in United States, although not legal in Albania, during his years in exile there and was ordained its priest.

The declaration of the Albanian independence in 1912 and the subsequent foundation of the Albanian State brought the possibility for the realization of many ideas and thoughts of its patriots. The existence of the Albanian state would facilitate, accelerate, and enforce the consolidation process of its nation, but, the newly born Albanian State was weak and fragile. The consolidation of the Albanian State was reached during the years 1920-1939. More generally, the beginning of the 20th century marks essential historical, religious and cultural changes of Albania.

The Congress held in Berat in 1922 by Albanian patriots founded the KOASH (Kisha Ortodokse Autogefale Shqiptare) Albanian Autocephalous Orthodox Church. The outcome of this Congress was the independence of the Albanian Orthodox Church from the Greek Patriarchate. The Muslim Congress of Albanians held in 1923, the first Muslim Congress of Albanians, declared the Albanian Muslim branch independent from Shaykh-ul-Islam. These events were followed by many other changes like the removal or the ban of the veil (a Muslim tradition) and the reduction in the number of the mosques [Moroco dela Roka, R 1994].

These changes were hosted with magnificent ceremonies by the people in many Albanian cities. We can mention the most welcomed Congress, that of Berat, which founded the KOASH (Kisha Ortodokse Autogefale Shqiptare) Albanian Autocephalous Orthodox Church. The days of the Congress works were filled with organized ceremonies held by Albanian Orthodox collectively with members of other religious beliefs. These ceremonies took place not only in Berat but in all cities and villages, mostly of the southern Albania. The Congress received many congratulating letters from all cities of the country (Shkodra, Tirana, Berati, Lushnja, Gjrokastra, Vlora, Kavaja ect.). In one of these letters was emphasized the spirit of nationalism that was granted to the Orthodox Church by this Congress [Naska, K. 1993, 17-18].

The result of these changes was the complete independence of Albania as well as the consolidation of Albanian identity. Albanians felt as members of one community. For the first time they felt as members of Albanian religion, though 
they belonged to different religious groups. This way religion -though divided in many religious beliefs- assisted in the consolidation of the Albanian national identity as well as in the consolidation of the common culture. The consolidation of the Albanian nation became possible though its members belonged to diverse religious beliefs.

The complete consolidation of the Albanian nationalism required the negligence toward different religious beliefs as well as their independence; making different Albanian religions really Albanian capable of embodying the Albanian identity in the foreground. The negligence toward different religious beliefs made possible for nationalism to replace religious feelings. The independence of Albanian religions, on the other hand, assisted in the total consolidation of the Albanian nationalism.

As a conclusion we can maintain that a nation can be consolidated even in the absence of a common religion. Though the emergence of Albanian nationalism became evident only in the 19th century - almost one century after the birth of nationalism in Europe- and although it was a multi-religions nation, its consolidation was in actual fact successful and we can even argue that it was the nation itself which endeavored to create its state till this became reality in 1912. The Albanian case demonstrates that if the emotional bond and mobilization of a group is obvious, "groups for which members are willing to give their lives" [Marvin C. \& Ingle D. 1996], the common religion is not an indispensible component. Furthermore, nationalism can even replace different religious beliefs; or, as the case of United States demonstrates, nationalism can be equalized with religious feeling and even be considered as the most powerful religion. Form these two cases -United States and Albania- we can conclude that the consolidation of a multi-religions nation is possible in both cases 1) when members have a common origin and history as in the case of Albania, 2) when its members do not share a common origin, as in the case of United States. Therefore, the common religion and the common origin (as the case of United States demonstrates) are not indispensible components or elements of nationalism. The view in this conclusion is that, as constructivists argue, nations are imagined and can be engineered [Anderson, B. 1991].

The consolidation of the nation in the absence of a common religion, and even in the absence of a common origin as in the case of United States, argues for the acknowledged power of the emotional mobilization of a group (nation) [Smith 1991, 176], or as Marvin C. \& Ingle D. [1996] describe it "groups for which members are willing to give their lives"; an emotional appeal which is capable to equalize religion with the nation or to replace religions by nationalism when its existence is jeopardized.

\section{Method}

The major method used is the comparative politics. This method compares two cases by highlighting the similarities between them. The similarities between the two cases can be easily inferred, and even are at all times true, for generalizations. In the end, this essay reaches a generalization which is in accordance with Marvin's and Ingle's [1996] generalization.

The case study method coupled with analyses has been used in order to compare the two cases. I have also used the top bottom as well as the bottom up approaches. The top bottom approach is to analyze how the state or patriots influenced and assisted in the consolidation of Albanian nationalism. The bottom up approach is to analyze how the people itself responded to the proclamations of their elites and patriots.

\section{Findings}

The major finding/generalization reached is that a nation can be consolidated even its members belong to different religious beliefs; as the two cases demonstrate. The condition for this has been the emotional mobilization of the group (nation) [Smith 1991, 176], or as Marvin C. \& Ingle D. [1996] describe it: "groups for which members are willing to give their lives". When the emotional mobilization is obvious, as the Albanians demonstrated in the League of Prizren founded in 1878, nationalism can replace and overshadow religions. I used the word 'consolidate' for the Albanian case because the Albanian nation, in some way, had began to take shape even prior to 1878 , but, the United States' case -which does not have an inherited nation as Albania- leads to the conclusion/generalization that a nation can be 'created' even if its members belong to different religious beliefs.

\section{Discussion}

The formation of Albanian nation leads to two different discussions: 
The first is the broadest one and has to do with the theories of nationalism; is the common religion indispensible for the complete formation of a nation? Superficially, the answer seems to be yes because of the contribution the common religion gives to the national identity and unity.

If we infer from the case of Albanians, we may argue that the kind of negligence Albanians have toward religions cannot be applicable to other nations and the answer would be yes. On the other hand, the raw fact that the Albanian nation exists means that the common religion is not indispensible for the formation of a nation. Furthermore, the successful formation of the United States' nation composed of believer members belonging to different religious beliefs shows that the common religion is not indispensible for the complete formation of a nation.

The second discussion has to do with Albanians. Are the nowadays Albanians atheists or they have inherited the negligence toward religious beliefs from the past? The negligence that the patriots of the Albanian Resurrection (18301912) embodied to Albanians as well as the denial of religions during the communist period suggest that they have inherited the negligence toward religious beliefs from the past, but, the facts presented in this essay demonstrate that they have the spirit of nationalism; their main identity is being Albanian which, if is jeopardized, is capable of overshadowing other identities.

\section{References}

[1] Anderson, B. (1991). Imagined Communities. Revised Edition. Verso. London: New York.

[2] Brubaker Rogers (2011). Religion and Nationalism: Four Approaches. Available in: http://www.sscnet.ucla.edu/soc/faculty/brubaker/Publications/religion_and_nationalism_forthcoming.pdf

[3] Hawking S. (2013). Nationalism as Religion. Available in: http://genealogyreligion.net/the-religion-of-nationalism

[4] Kodi Civil i vitit 1929. Mbretnia Shqiptare, Ministria e Drejtesise. Tirane, Toena,1998. Kaptina III. Celebrimi i marteses. Neni 149.

[5] Kristaq, P. (1993). Themelimi I Kishes Ortodokse Autoqefale Shqiptare -Ngjarje e Rendesishme Historine e Kombit Shqiptar. 70 Vjet te KOASH. Akademia e Shkencave. Instituti I Historise. Tirane.

[6] Marvin C. \& Ingle D. (1996). Blood Sacrifice and the Nation: Revisiting Civil Religion. To be published in the Journal of American Academy of Religion 64: (4), Winter, 1996. Available in: http://www.asc.upenn.edu/usr/fcm/jaar.htm

[7] Moroco dela Roka, R (1994). Kombesia dhe feja ne Shqiperi 1920-1924. Tirane, Elena Gjika,

[8] Naska, K. (1993). Kongresi Themeltar I Kishes Ortodokse Autoqefale ne Berat. 70 Vjet te KOASH. Akademia e Shkencave. Instituti I Historise. Tirane.

[9] Pepa, P. (2007). Tragjedia dhe lavdia e klerit katolik ne Shqiperi, Vol 1. Tirane, Shtepia Botuese 55.

[10] Puto, A. (2009). Shqiperia politike 1912-1939. Tirane, Toena.

[11] Smith, A. (1991). National Identity. London: Penguin Books. 